\title{
PENGEMBANGAN BAHASA IBU (BAHASA SUNDA) YANG BERKARAKTER UNTUK ANAK USIA DINI

\author{
Etty Rohayati ${ }^{1}$
}

\begin{abstract}
ABSTRAK
Manusia lahir ke dunia sudah diberi bekal untuk berbahasa, misalnya pada keterampilan menyimak dari sejak janin dalam kandungan ada kontak batin dengan perasaan ibu yang mengandungnya. Pada keterampilan berbicara, begitu lahir bayi langsung menangis karena ada sesuatu yang dirasakan pada dirinya mungkin sakit, lapar, haus, atau kurang nyaman. Hal ini menandakan adanya pralanguage.

Keterampilan berbahasa tidak langsung bisa tapi adanya proses. Contoh dengan adanya pemerolehan bahasa anak dari mulai mengungkapkan vokal, suku kata, kata, dua kata sampai mengungkapkan kalimat sederhana yang mengandung gramatikal faktor-faktor yang mempengaruhi pemerolehan bahasa di antaranya; (1). Faktor Biologis, (2). Faktor Lingkungan Sosial (3). Faktor intelegensi dan (4). Faktor motivasi.

Perkembangan bahasa ibu yang berkarakter untuk usia dini dimulai sejak janin dalam kandungan, setelah lahir pemerolehan bahasa ibu, anak dibimbing dengan bahasa yang berkarakter di antaranya; (1). Cinta Tuhan dan segenap ciptaan-Nya (2). Kemandirian dan tanggung jawab (3). Kejujuran atau amanah, diplomatis (4). Hormat dan santun (5). Dermawan, suka tolong-menolong dan gotong-royong (6). Percaya diri dan pekerja keras (7). Kepemimpinan dan keadilan (8). Baik dan rendah hati (9). Toleransi, kedamaian dan kesatuan.
\end{abstract}

\section{Kata Kunci : Pengembangan Bahasa, Karakter}

\section{A. PENDAHULUAN}

Bahasa adalah alat komunikasi untuk menyampaikan pesan, informasi, gagasan atau ide, karena dengan bahasa dapat mengembangkan kemampuan untuk bergaul (social skill) dengan orang lain. Tanpa bahasa baik secara lisan, tulis, atau isyarat tak mungkin bisa berkomunikasi. Fungsi dari bahasa, anak dapat mengekspresikan pikiran, gagasan, ide dan perasaannya, sehingga bisa terjalin baik dalam berkomunikasi dengan teman sebayanya.

Kemampuan keterampilan berbahasa yang berkarakter itu tidak datang dengan sendirinya, tetapi melalui proses yaitu dengan pemerolehan, belajar dan bimbingan. Misalnya dalam proses penyimakan bukan saja dimulai sejak bayi sudah lahir, tapi sewaktu janin masih dalam kandungan, ibunya harus membiasakan diri dengan kegiatan positif, memperhatikan nasihat orang tua, adat kebiasaan yang baik dan bermanfaat. Menghindar dari perbuatan negatif atau larangan-larangan lainnya yang diutarakan oleh orang tua, dan selalu ingat pada janin yang dikandungnya, karena bayi dalam kandungan mempunyai ikatan

\footnotetext{
${ }^{1}$ Dosen PGPAUD UPI Kampus Cibiru
} 
emosional dengan ibunya. Hal ini sudah dimulai mendidik anak yang berkarakter sejak dalam kandungan.

Pada keterampilan berbicara, dimulai sejak anak dilahirkan dia menangis ini merupakan pralinguistik, maksudnya menangis itu karena ada sesuatu yang dia rasakan pada dirinya, misalnya karena haus, lapar, ngompol, kurang nyaman atau sakit. Kemudian dapat mengungkapkan vokal, suku kata, kata, dua kata sampai kalimat sederhana. Dalam kemampuan berbicara anak secara berangsur atau bertahap.

\section{B. PEMEROLEHAN BAHASA IBU}

Kemampuan keterampilan berbahasa pada anak tidak akan langsung dikuasai dengan sendirinya, tetapi anak akan mendapatkannya secara berangsur dan bertahap. seperti halnya penyimakan, kalau kita amati penyimakan pada anak itu terjadi sewaktu janin masih dalam kandungan, karena ibu yang mengandung akan merasakan kontak pada perasaan, kondisi dan situasi dengan janin yang dikandungnya. Contohnya; apabila seorang ibu hamil pada waktu mendapat musibah atau kekecewaan maka janin yang dikandungnya kontak merasakan penderitaan itu. Begitu juga dengan kebahagiaan yang dialami ibunya janin dalam kandungan dengan sering bergerak.

Setelah anak dalam kandungan itu lahir dia akan memiliki keterampilan berbicara secara bertahap dengan kedewasaan atau umurnya. Sesuai hasil penelitian para ahli dapat disimpulkan bahwa pada umur 0-12 bulan pemerolehan berbicara secara bertahap.

Umur 0-2 bulan tahap pralinguistik yaitu anak akan mengeluarkan bunyibunyi refleksi untuk menyatakan lapar, sakit, dan ketidaknyamanan yang menyebabkan anak menangis atau rewel. Serta bunyi vegetatif yang berkaitan dengan aktivitas tubuh seperti batuk, beresin, sendawa. Meskipun bunyi-bunyi itu tidak bermakna tetapi merupakan bahan tuturan selanjutnya. Misalnya jika anak bersin orang tua langsung mengucapkan "Yarhamu kallah" atau dalam bahasa Sunda orang tua mengucapkan "Hurip Waras”.

Umur 6-12 bulan anak mulai berceloteh mengucapkan kata-kata yang paling dekat dengan lingkungan kehidupan seperti kata mamah, yayah, nene, nenen, eueu, mamam. Perkembangan ini akan lebih kaya perbendaharaan bahasanya jika orang tua atau yang dekat dengan anak itu peduli untuk membimbing ungkapan -ungkapan yang lain.

Umur 12-18 bulan, adalah tahapan satu kata (tahap holofirasis) yaitu fase perkembangan bahasa anak yang umumnya mampu mengungkapkan ujaran satu kata. Dengan satu kata itu bermaksud mengungkapkan ide tuturan yang lengkap . contoh kata eu eu sambil menunjukkan gelas. Ungkapan eu eu maksudnya saya minta minum, mamam sambil menunjuk makanan, saya minta makan dll.

Umur 18-24 bulan tahap kemampuan anak menuturkan 2 kata tuturannya bersifat telematik maksudnya kata yang dituturkan anak hanyalah kata-kata penting saja cotohnya "mamah mamam" maksudnya "mamah saya mau makan" “dede papang” sambil menunjukkan celana yang dipakainya basah maksudnya celana basah karena dede sudah pipis. 
Umur 3-5 tahun tahap kemampuan anak dengan tuturan lebih dari tiga kata dengan penguasaan gramatikal yang lebih baik. Tahap-tahap perkembangan bahasa anak menurut Piaget dan Vygotsky (dalam Tarigan 1988)

\begin{tabular}{|c|l|}
\hline Usia & \multicolumn{1}{|c|}{ Tahap Perkembangan Bahasa Anak } \\
\hline $0,0-0,5$ & Tahap Meraban (Pralinguistik) Pertama \\
\hline $0,5-1,0$ & Tahap Meraban (Pralinguistik) Kedua: Kata nonsense \\
\hline $1,0-2,0$ & Tahap Linguistik I: Holofrastik; Kalimat satu kata \\
\hline $2,0-3,0$ & Tahap Linguistik II: Kalimat dua kata \\
\hline $3,0-4,0$ & Tahap Linguistik III: Pengembangan tata bahasa \\
\hline $4,0-5,0$ & Tahap Linguistik IV: Tata tahasa Pradewasa \\
\hline 5,0 & Tahap Linguistik V: Kompetensi penuh. \\
\hline
\end{tabular}

\section{PENGEMBANGAN BAHASA IBU}

Bahasa berkembang mengikuti perkembangan waktu dan zamannya. Kemajuan dalam perkembangan bahasa ibu tidak terlepas dari pengaruh-pengaruh yang di antaranya:

1. Faktor biologis; maksudnya yang menentukan pemerolehan bahasa ibu (bahasa Sunda) adalah sistem otak (syaraf pusat), alat pendengar, dan alat ucap. Apabila sistem otak (syaraf pusat) terganggu, maka khususnya pada keterampilan berbahasa juga akan terganggu, misalnya lambat dalam berbicara, gagap, atau latah. Begitu juga terganggunya alat pendengaran, pada umumnya erat sekali dengan keterampilan berbicara. Anak yang mengalami gangguan tersebut langsung akan menderita pireu (pego) tidak bisa berbicara. Begitu juga gangguan pada alat ucap, anak yang mengalami gangguan alat ucap akan mengakibatkan cadel atau kurang jelas pengucapannya dalam berbicaranya.

2. Faktor lingkungan sosial, yang dimaksud dengan lingkungan sosial di sini adalah tempat tinggal dan tumbuh anak dalam kehidupan sehari-harinya, seperti lingkungan keluarga, dan masyarakatnya. Hal ini sangat penting pada kemajuan perkembangan bahasa ibu, karena untuk berkomunikasi dan bersosialisasi anak memerlukan kehadiran orang lain. Kalau kita simak bahasa ibu yang diperoleh anak itu tidak diwariskan semata-mata atau secara genetik, tetapi didapatkan dari orang tua atau orang terdekat dengan anak di lingkungan keluarga dan masyarakatnya. Dalam perkembangan bahasa ibu anak masih memerlukan contoh, model bahasa, respons dan tanggapan serta teman untuk berlatih dan beruji coba belajar bahasa dalam konteks yang sesungguhnya. Orang tua yang menerapkan bahasa nasional (bahasa Indonesia) pada anak dalam tumbuh kembang sehari-hari di lingkungan bahasa ibu, mereka beranggapan dengan tindakan itu anak akan lebih berhasil dan berprestasi, padahal secara tidak langsung tindakan itu merupakan pemerkosaan pada kemajuan perkembangan berbahasa anak sediri. Anak yang memakai bahasa ibu di lingkungan bahasa ibu sendiri akan mudah berkomunikasi, bersosialisasi, berapresiasi, beradaptasi dengan teman sebaya, keluarga dan masyarakatnya. Jika anak itu masuk sekolah dasar (SD), untuk di kelas rendah guru diberi toleransi pengantar pelajaran atau dalam 
menyampaikan pelajaran dengan bahasa ibunya, dan untuk kelas lanjut (kelas tinggi) guru tidak diperbolehkan menggunakan pengantar pembelajaran dengan bahasa ibu (bahasa Sunda), kecuali pembelajaran bahasa daerahnya. Kenyataan di lapangan anak akan lebih mudah atau berhasil dalam mengungkapkan bahasa nasional (bahasa Indonesia) karena semua mata pelajaran kecuali bahasa daerah harus memakai bahasa Indonesia. Dengan demikian anak akan memperoleh dwibahasa, yaitu bahasa daerah atau bahasa ibu (bahasa Sunda) dan bahasa nasional (bahasa Indonesia).

3. Faktor intelegensi; yaitu kemampuan anak dalam berpikir atau bernalar. Orang terdekat dengan anak atau orang tua yang menerapkan kesehariannya dan membimbing dengan bahasa ibu (daerah Sunda) di keluarga atau lingkungannya, maka anak tidak akan mendapat gangguan atau canggung di dalam berpikir dan bernalarnya karena anak langsung dapat berkomunikasi, bersosialisasi dan berapresiasi dengan orang terdekat. Orang tua, teman sebaya, keluarga dan lingkungan masyarakatnya. Faktor intelegensi yang tinggi, tingkat pencapaian bahasa anak lebih cepat, lebih banyak perbendaharaan katanya, lebih bervariasi khasanah dalam berbahasanya.

4. Faktor motivasi; tingkat intelegensi pada anak tersebut tidak terlepas dari motivasi orang terdekat, orang tua, serta keluarga yang menerapkan dan membimbing pada kehidupan sehari-harinya dengan bahasa ibu dengan baik dan benar.

\section{PENGEMBANGAN BAHASA IBU (BAHASA SUNDA) YANG BERKARAKTER UNTUK ANAK USIA DINI.}

Kalau kita simak pada masa lampau ada seorang filosof besar yang sangat mengutamakan pendidikan yang berkarakter dalam kehidupan, yakni Nabi Muhammad saw. Yang dalam hadistnya” inna maa buuistu lii utamiimal karimah akhlaq" yang artinya "Sesungguhnya aku diutus ke dunia ini untuk menyempurnakan akhlak”, yang dimaksud akhlak adalah karakter yang baik dan terpuji.

Pendidikan yang berkarakter dimulai sejak janin masih dalam kandungan, karena ibu yang mengandung akan merasakan adanya kontak dengan janin yang dikandungnya. Sebagai contoh apabila ibu yang mengandung merasa khawatir, resah, kaget atau kesenangan sekalipun, maka bayi yang dikandungnya akan merasakan atau ada reaksi pada kandungan itu, dan sejak bayi dalam kandungan sudah memiliki ikatan emosional dengan ibunya. Ikatan psikologi ini berperan bagi anak untuk menentukan karakteristik yang nantinya bisa mempertahankan hidupnya.

Banyak sekali orang tua mengadakan syukuran, berdoa keselamatan, kesehatan, kesalehan, dan berkarakter mulia yang berguna bagi agama, nusa, dan bangsanya. Dari sejak janin berusia $3-4$ bulan atau sejak janin diberi ruh oleh Allah serta penentuan kodo dan kodar-Nya. Ada juga orang tua yang mengadakan tujuh bulanan yaitu upacara adat, yang banyak simbol-simbol dan intinya tidak terlepas dari berdoa untuk keselamatan hidupnya. Perhatian dari orang tua berupa nasihat-nasihat keharusan dan larangan (pantrangan) yang harus diperhatikan itu merupakan pendidikan pada janin dalam kandungan, contohnya; 
harus banyak mendekatkan diri pada yang Kuasa, berzikir dan beribadah, banyak membersihkan diri, merapikan, mempersolek diri, baik ruangan ataupun lingkungan setempat, begitu juga larangan- larangannya (pantrangan) misalnya tentang waktu, makanan, tempat dan sebagainya. Itu secara tidak langsung mendidik janin untuk membentuk karakternya.

Ketika bayi dilahirkan dengan potongan tali pusar yang menghubungkan bayi dan ibunya, maka kelekatan fisik menjadi terputus dan mulailah ikatan secara psikologis antara ibu dan anak. dari sejak lahir yang diharapkan orang tua adalah ada dalam lindungan Allah selamanya, bertakwa, dan jadi anak yang Soleh yang bermanfaat bagi agama, nusa dan bangsa, pertama kali yang dikumandangkan pada telinga bayi itu adalah azan. Hal ini bukan berarti mengajak salat pada bayi tetapi yang diharapkan pertama kali yang didengar bayi itu adalah Nama (Asma) Allah.

Usia 0-2 bulan anak mengeluarkan bunyi-bunyi refleksi untuk menyatakan lapar, sakit, dan ketidaknyamanan yang menyebabkan anak itu menangis atau rewel. Serta bunyi vegetatif yang berkaitan dengan aktivitas tubuh, seperti batuk, bersin, sendawa, meskipun bunyi itu tidak bermakna tetapi merupakan bahan tuturan selanjutnya. Sebagai bimbingan karakter dari orang tua terhadap anaknya. Apabila anak itu bersin maka orang tua mengucapkan doa "Yarhamuka Alloh" atau dalam bahasa Sunda orang tuanya mengucapkan "Hurip waras"

Usia 3-5 bulan anak mulai mendengkur dengan mengeluarkan bunyi-bunyi vokal yang bercampur dengan bunyi-bunyi konsonan, orang tua langsung membimbingnya dengan ucapan "hao hakeng” yang maksudnya adalah "Allah nu Langgeng” Tuhan yang Abadi.

Usia 6-12 bulan anak mulai berceloteh dengan mengucapkan kata-kata yang paling dekat dengan lingkungannya. Seperti kata mamah, yayah, nene, nenen, perkembangan itu akan lebih kaya perbendaharaan bahasanya jika orang tuanya peduli menuntun atau membimbing ungkapan-ungkapan yang lainnya dengan bahasa yang santun.

Usia 12-18 bulan adalah tahapan holofrase yaitu fase perkembangan bahasa anak yang umumnya mengungkapkan hanya satu kata, yang dekat dengan perilakunya misalnya dengan satu kata itu bermaksud mengungkapkan ide susunan yang lengkap misalnya. "Eueu” sambil menunjukan gelas, maksudnya saya mau minum. orangtua mengambilkan air di gelas dengan hati-hati dan meminumkannya dengan mengucapkan "bismilah", kebiasaan ini akan membimbing karakter pada anak untuk cinta Tuhan, kedisiplinan dan kepedulian. ungkapan "nenen” sambil membuka kancing depan kemeja ibunya, maksudnya "saya mau nete". Ibunya mengeluarkan susu dan dengan penuh kasih sayang langsung menyusui. Karakter yang ibu terapkan adalah kecintaan dan kasih sayang. Ungkapan "Papang” sambil berdiri maksudnya dia ingin ganti celana yang dipakainya, dll.

Usia 12-24 bulan fase kemampuan anak menuturkan dua kata, tuturannya itu bersifat telegrafik maksudnya kata yang dituturkan anak hanyalah kata-kata yang penting saja misalnya kata "mamah mamam”, maksudnya "mamah saya mau makan" dll. 
Usia 3-5 tahun tahap tuturan dengan banyak kata, yaitu anak mampu menuturkan dengan menggunakan tiga kata atau lebih dengan penguasaan gramatikal yang lebih baik. Hal ini orang tua atau orang yang terdekat dengan anak itu harus membimbing dengan menerapkan pengungkapan kata-kata serta tutur kata yang betul dan baik. Karena anak seusia ini sedang mengikuti pembicaraan yang diungkapkan orang lain dan orang tua sering memberi peringatan "budak keur tuturut munding" hati-hati berbicara dihadapan anak karena anak tersebut sedang meniru pengucapan orang dewasa.

Usia 5 tahun ke atas adalah tahap linguistik kompetensi penuh, pada tahap inilah kita harus membimbing dan membangun kreativitas yang berkarakter. Hal tersebut dapat disimpulkan pendidikan yang berkarakter itu dapat dilaksanakan di antaranya melalui pendidikan dan latihan secara informal, formal, dan nonformal. Sesuai dengan pendapat Maswardi (2011.43) bahwa "untuk menginternalisasikan pendidikan karakter/budi pekerti dalam rangka membangun karakter/budi pekerti anak bangsa adalah melalui (1). Pendidikan informal, (2). Pendidikan Formal dan (3). Pendidikan Non formal”.

1. Pendidikan informal (informal Education) pendidikan yang pertama kali diterima oleh anak yaitu pendidikan dalam keluarga. Hal ini sangat menentukan karakter anak. Keteladanan orang tua sangat menentukan, jadilah orang tua yang diidolakan dan diteladani anak-anaknya. Pendidikan karakter untuk anak bukan sekadar dikenal dan dihafal tetapi harus dibimbing dan dibiasakan berbuat baik dalam kehidupan sehari hari. Misalnya; Mengenal Tuhan dengan ucapan yang sederhana contohnya, Allah, Allahhu Akbar, Bissmillah, Assalamu’alaikum, belajar mengaji atau menghafal huruf-huruf dalam AlQuran seperti Alif,Ba,Tha, Sha, dsb. Membiasakan salat (sembahyang) berjamaah, berdoa. Mendidik jujur, amanah, toleransi. Membiasakan minta izin bila hendak pergi dengan minta Doa restu orang tua dan mencium tangannya. Menyapa orang yang lebih tua dengan sapaan yang menunjukkan rasa hormat.

2. Pendidikan Formal (Formal Education) pendidikan yang diadakan secara resmi dengan penuh aturan yang harus ditaati oleh pesertanya. (UUD No. 20/2003 pasal 1(1) menyatakan bahwa "Pendidikan Formal adalah jalur pendidikan yang terstruktur dan berjenjang yang terdiri atas pendidikan dasar, pendidikan menengah, pendidikan tinggi” pendidikan karakter bisa dimaksudkan pada setiap pembahasan materi, misalnya memberikan nasihat, arahan, petuah, bimbingan untuk berbuat kebaikan, dsb. Perkataan, perbuatan, perilaku, ketaatan beribadah, cara berpakaian, kedekatan guru/dosen yang ramah semua itu merupakan teladan bagi peserta didik. Guru/dosen yang baik dan profesional adalah yang bertanggung jawab dan mampu menghayati serta mengamalkan empat kompetensi secara umumnya di antaranya; kompetensi pedagogik, kompetensi sosial, kompetensi profesional, dan kompetensi kepribadian.

3. Pendidikan Non- Formal (Non-Formal Educatian) adalah pendidikan pengganti atau penambah atau pelengkap pendidikan formal yang diselenggarakan oleh masyarakat atau yayasan tertentu. Pendidikan nonformal 
berfungsi untuk mengembangkan potensi peserta didik yang menekankan pada penguasaan dan pengetahuan

\section{DAFTAR PUSTAKA}

Dinas Kabupaten Sumedang. (2009). Pelatihan Tenaga Pendidik Pendidikan Anak Usia Dini (PAUD). Sumedang: Depdiknas.

http://www.scribd.com/doc/59437900/17/Perkembangan-Bahasa-Anak

Muhammad A. Maswardi. (2011). Pendidikan Karakter Anak Bangsa., Jakarta: Badause Media.

Universitas Pendidikan Indonesia. (2009) Bahan Ajar Pendidikan dan Latihan Profesi Guru. Bandung: UPI Press.

Tarigan, H.G. 1988. Pengajaran Pemerolehan Bahasa. Bandung: Angkasa.

Zuchdi, Darmiyati dan Budiasih. 1996. Pendidikan Bahasa dan Sastra Indonesia Di Kelas Rendah. Jakarta: Depdiknas 